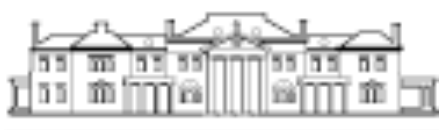

- The Levy • Economics Institute of Bard College

Working Paper No. 548

\title{
On Democratizing Financial Turmoil: A Minskian Analysis of the Subprime Crisis*
}

\author{
by \\ Luisa Fernandez \\ Alvarez \& Marsal Taxand, LLC \\ Fadhel Kaboub \\ Denison University \\ Zdravka Todorova \\ Wright State University
}

November 2008

\begin{abstract}
* Paper presented at the Annual Eastern Economics Association Conference in Boston, MA (March 7-9, 2008). Any views expressed in this paper are those of the authors only and not those of Alvarez \& Marsal Taxand, LLC. The authors wish to thank Justin Hess (Denison University, Class of 2010) for his excellent editorial assistance. The usual disclaimer applies. Corresponding author: Fadhel Kaboub, Denison University, Department of Economics, 227 Higley Hall, 100 West College Street, Granville, OH 43023; tel.: (740) 587-6315; e-mail: kaboubf@denison.edu
\end{abstract}


The Levy Economics Institute Working Paper Collection presents research in progress by Levy Institute scholars and conference participants. The purpose of the series is to disseminate ideas to and elicit comments from academics and professionals.

The Levy Economics Institute of Bard College, founded in 1986, is a nonprofit, nonpartisan, independently funded research organization devoted to public service. Through scholarship and economic research it generates viable, effective public policy responses to important economic problems that profoundly affect the quality of life in the United States and abroad.

The Levy Economics Institute P.O. Box 5000

Annandale-on-Hudson, NY 12504-5000

http://www.levy.org

Copyright (C) The Levy Economics Institute 2008 All rights reserved. 


\begin{abstract}
The paper uses Minsky's financial instability hypothesis as an analytical framework for understanding the subprime mortgage crisis and for introducing adequate reforms to restore economic stability. We argue that the subprime crisis has structural origins that extend far beyond the housing and financial markets. We further argue that rising inequality since the 1980s formed the breeding ground for the current financial markets meltdown. What we observe today is only the manifestation of the ingenuity of the market in taking advantage of moneymaking opportunities, regardless of the consequences. The so-called “democratization of homeownership” rapidly turned into record-high delinquencies and foreclosures. The sudden turn in market expectations led investors and banks to reevaluate their portfolios, which brought about a credit crunch and widespread economic instability. The Federal Reserve Bank’s intervention came too late and failed to usher in adequate regulation. Finally, the paper argues that a true democratization of homeownership is only possible through job creation and incomegeneration programs, rather than through exotic mortgage schemes.
\end{abstract}

Keywords: Minsky; Financial Instability; Wall Street; Subprime Mortgages; Real Estate; Full Employment; Inequality

JEL Classifications: B52, B58, E12, E44, B52, G21, G24 


\section{INTRODUCTION}

On June 17, 2002, President Bush declared that "There is a home ownership gap in America. The difference between Anglo-American and African-American and Hispanic home ownership is too big. And we've got to focus the attention on this nation to address this” (The White House 2002). The goal was to increase minority home owners by at least 5.5 million by 2010. In August 2004, the White House produced a document surveying President Bush’s achivements. The document stated that “The U.S. homeownership rate reached a record 69.2\% in the second quarter of 2004. The number of homeowners in the United States reached 73.4 million, the most ever. And for the first time, the majority of minority Americans own their own homes” (The White House 2004: 44). Unfortunately, the short-lived increase in homeownership was followed by a recordhigh foreclosure avalanche that has pushed the U.S. economy into one of its worst financial crises since the Great Depression. Billions of dollars in asset write-downs, rising unemployment, sluggish economic growth, and record-high oil and food prices, all of which add up to the end of what has been termed "the democratization of homeownership.” This fictitious "democratization” was only made possible by a combination of factors, namely, three decades of financial deregulation, a very-lowinterest-rate policy by the Fed, an aggressive lending strategy by mortgage companies and banks seeking fees and commissions, and a set of financial innovations allowing mortgage loan issuers to unload their loan burden onto Wall Street to be securitized and marketed without any serious supervision or regulation.

The argument made in this paper illustrates that the subprime crisis is yet another classic Hyman Minsky episode of financial instability. "Stability breeds instability" is a famous Minsky slogan, meaning that financial instability and economic turmoil are endogenous phenomena that stem from the over-optimistic sentiments and confidence that overtake the economy during a boom, leading to lower standards of investment evaluations and thinner cushions of safety. Pushing Minsky's argument a bit further, we argue that "inequality breeds instability" as well. The stagnation of real income for economically disadvantaged households (typically non-homeowners) combined with ever-increasing real estate prices meant that those households would never be able to 
achieve homeownership. Such households would only be able to buy homes under one of the following scenarios: 1) real income rise; 2) real estate prices decline; or 3) government subsidies (downpayment assistance and low fixed interest rates). Unfortunately, the rise in homeownership achieved in 2004 and 2005 was not due to any of the above scenarios. The "democratization" of homeownership was nothing but a fictitious increase in the demand for homes fueled by innovative financing schemes that misled residential real estate developers into increasing the supply of new homes and setting up the industry for one of its worst declines in decades. We argue that this fictitious democratization of homeownership has turned into a real democratization of financial turmoil that has spread beyond subprime borrowers and the herds of lenders who serviced them.

The paper is organized as follows. Section II presents the mainstream explanation of financial crisis as being the result of "bubbles and irrational exuberance," and contrasts this with a Minskian explanation of endogenous instability. In section III we look at some empirical evidence on the mortgage loans serviced, delinquencies, and foreclosures, with a particular focus on the East North Central, Middle Atlantic, and South Atlantic regions of the United States. Section IV argues that inequality has been the real cause of financial crisis and that the subprime lending frenzy was just a temporary patch on inequality in which the economically disadvantaged have been used to ride a wave of Wall Street speculation. Finally, we conclude that the only viable means of achieving higher rates of homeownership and economic stability is through a full employment program that secures stable employment opportunities with decent wages and benefits. Under such program, all households will have a real and sustainable opportunity for homeownership.

\section{MAINSTREAM VS. MINSKIAN EXPLANATIONS OF THE SUBPRIME CRISIS}

\section{A. The "Bubble and Exuberance" Explanations}

In general, irrational exuberance, mania, or bubbles are the usual mainstream explanations of financial instability. These are expression of failure of the agents in the system to behave rationally. Financial instability is presented as unusual to the market 
system, where individuals act rationally. In the current subprime crisis these are offered as explanations, too-exuberance on the part of the homeowners who knew they couldn't afford the mortgages they undertook and bubbles resulting from overpricing real estate property. Following this logic, the advice is to allow financial markets to learn the hard way by letting agents go bankrupt. The presumption is that most of the time there is natural stability in the system.

Just the opposite is suggested by J.M. Keynes’s analysis of expectations about investment returns under uncertainty — the so-called "animal spirits” are a major element of the capitalist system. Expenditures on current investment represent an exchange of money today for money tomorrow under specific expectations about returns in the future. Under conditions of uncertainty, it is only natural that these expectations will be disappointed (alternatively we would have rational expectations). Jan Kregel (2007), following Keynes, emphasizes the natural instability of financial markets.

Similarly, L.R. Wray (2007) points out the importance of going beyond the bubble and exuberance explanations of financial instability and looking at the systematic conditions embedded in financial markets, including the role of economic policy, in validating behavior that enhances financial fragility.

Blaming the "bubble" for the current crisis is rather like blaming the car for an accident-when we ought to take a good long look at the driver, and at the bartender who kept the whiskey flowing all evening before helping the drunk to his car after last call... Unfortunately, those in charge of the financial system have for a very long time encouraged a blurring of the functions, mixing drinking and driving while arguing that the invisible hand guided by self interest can keep the car on course. The current wreck is a predictable result. (Wray 2007)

This predictability refers to the socially created conditions in financial markets and does not imply that we could deal away with financial fragility, but merely adjust through policy and regulation so that the economy does not slip into debt deflation of a depression magnitude. 


\section{B. A Minskian Explanation}

Hyman Minsky’s (1919-1996) financial instability hypothesis is a theory of the impact of debt on investment and presents a model of a capitalist economy that doesn't rely on exogenous shocks to generate business cycles. The structure of a capitalist economy becomes more fragile over a period of prosperity and an endogenous process leads to financial and, consequently, economic instability (Minsky 1992b).

Charles Whalen (2007) points out the relevance of the financial instability hypothesis to the current situation. This interpretation became somewhat visible in popular media, specifically in a Wall Street Journal article by Justin Lahart (2007). Minsky himself recognized the potential destabilizing effects of securitization as early as 1986-87 in a previously unpublished note that has been released by the Levy Economics Institute (Minsky 1986b, 2008). ${ }^{1}$

First, real estate appeared to be a good investment, and relatively safe too, especially when compared with the dotcom investments. Expansion of lenders' markets into less and less creditworthy borrowers began with "financial innovations" such as “interest-only” mortgages and “option adjustable rate” mortgages with low payments at the outset, but skyrocketing monthly payments later.

Unregulated mortgage brokers don't hold the loans and, thus, don't have a longterm relationship with the borrowers, so they are not concerned with their creditworthiness, rather they work for commissions. Since adjustable rate mortgages are highly profitable for banks, brokers received high commissions to generate these loans.

Banks’ desire for the expansion of markets (or “democratization” of credit) and the incentives to push adjustable rate mortgages, coupled with the tendency to overvalue real estate on behalf of commission-driven home appraisers, provided the foundations of financial instability. This was particularly true in the face of increasing default risk from subprime lending and unmet expectations regarding valuation of real estate assets.

Further, fragility is added to the system by banks that bundle mortgages into mortgage-backed securities (MBS) and sell them as a package to investment funds that used these MBS bundles as collateral for highly leveraged loans. The mortgages are

\footnotetext{
${ }^{1}$ Minsky warned that the securitization frenzy must be countered with strict regulations because "all that was required for the originators to earn their stipend was skill avoiding obvious fraud and in structuring the package” (Minsky 1992a: 22-23).
} 
bundled in varieties of risk classes, so that buyers could choose some option of perceived risk-to-return ratio. Furthermore, these loans were increasingly used to buy more mortgage bundles. This process of securitization, in particular, fits well Minsky's financial instability hypothesis, as the purchase of mortgage bundles and the financial derivatives (such as futures and options trading) involve expectations under uncertainty rather than simply skillful management of probabilistic risk.

As a guide to the likelihood of default, the credit rating agencies rate the debt packages for the banks that sell them. However, the rating agencies get paid by the issuers of the securities, not by investors, so there is pressure to give better ratings or else they face the danger of losing business to other rating agencies. Investors' motivations in purchasing such securitized assets were driven by optimistic expectations under conditions of expansion, as described by Minsky (1986, 1992a).

With increased incidents in homeowners' default, Minsky’s “debt-deflation” follows. Homes are not selling, developers are slashing prices to reduce their inventory, brokers are going out of business, appraisers also are negatively affected, investment banks are holding mortgages they cannot sell, investors are trying to sell out positions (assets are devalued), rating agencies are downgrading securities, and the insurers are facing tremendous losses.

In addition to the financial instability hypothesis, some authors following Keynes and Minsky have pointed to the institutional evolution in the U.S. financial markets—and specifically to the role of changes in regulations-in particular, deregulation (Kregel 2007; Wray 2007). Most notorious is the 1999 Bank Reform Act, which allows banks to engage in a larger range of financial activities (blurring the distinction between commercial and investment banking) under a larger degree of deregulation (Kregel 2007). Under these conditions, banks offer and promote increasingly bolder financial innovations.

Kregel specifically points to the evolution in the banker-borrower relation, where solvency and repayment of loans are no more the major concern for banks, since interest payments are displaced by fees as a source of profits. The ability of banks to earn fees for loan origination, while at the same time escaping the risk of default by selling the loan through securitization, is a major element of the current problem, as banks were not 
concerned with repayment of the loans, but with expansion of their markets and generating more fee revenues by originating new loans.

Economic policies that validate practices which actually contribute to financial fragility have also been identified as a structural problem (Wray 2007). Thus, the socalled "affordability loans” (the adjustable rate mortgages) that were part of the expansion of banks' market and strategy to obtain ever-expanding fee revenue from loan originations was validated by the Fed. Specifically, Greenspan encouraged homebuyers to undertake such loans. In addition, the acceptance of credit agencies (who represent a conflict of interest) as a viable valuation mechanism for risk is also a policy validation within the increasingly fragile financial system.

In addition to deregulation, globalization also plays into the current crisis. Globalization further stimulates the practice of securitization, as the latter creates and distributes financial paper across national borders. Indeed, the value of securitized mortgages exceeds the value of national debt held by foreign investors (Wray 2007: 7). Ironically, securitization has been offered as a financial innovation, which, at the macro level, is supposed to enhance risk management in the global economy (Bernanke 2004; Chancellor 2007). It was thought that MBS securitization into further collateralized debt obligations (CDOs and CDO2) would be a good risk-sharing mechanism that would spread the risk too thin and would allow investors to choose investments based on their taste for risk. The result, however, was that all investors ended up having the same risk exposure, hence, spreading financial instability across the economy.

\section{Inequality Breeds Instability}

In The General Theory (1936), Keynes identified economic inequality as one of the major destabilizing features of the capitalist system. In the 1960s, Minsky poured a considerable amount of ink working on the so-called War on Poverty. He was convinced that job creation for people with any level of qualification was the only true way to fight poverty and inequality. In this section we argue that the ongoing subprime crisis may appear to be the result of recent financial innovations gone wild, but a major contributing factor to the conditions leading to aggressive subprime lending behavior is the build-up and persistence of economic inequality that has intensified since 1980 in the United States. 


\section{Graph 1. Gini Ratio for U.S. Households (1967-2006)}

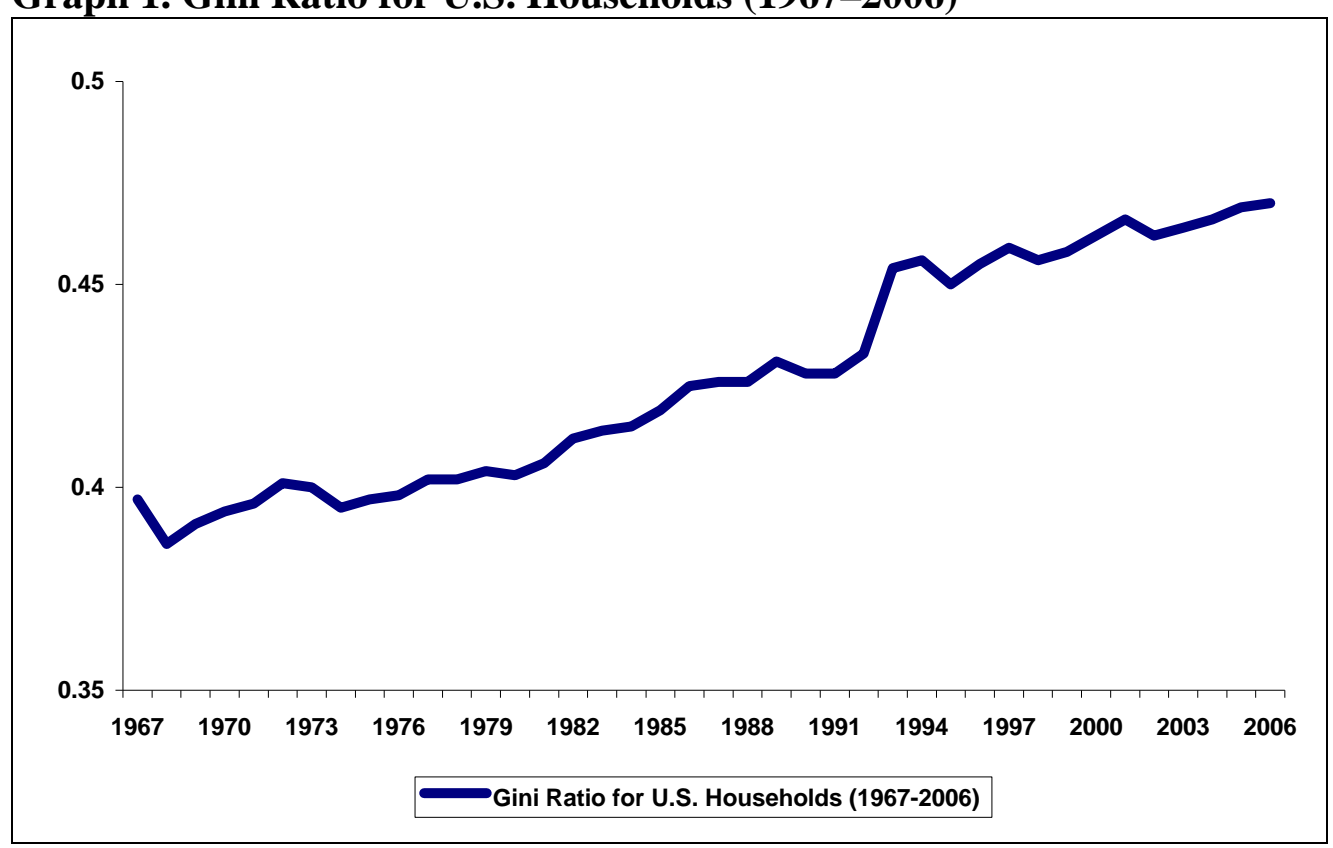

Source: U.S. Census Bureau, Historical Income Tables, Households, Table H-4

Between 1980 and 2004, the real average hourly wage (in 2004 dollars) hardly changed from its 1980 level of \$15.68/hour (\$15.67/hour in 2004). However, worker productivity has increased by 68\% over the same period (United for a Fair Economy 2006: 12). Even the federal minimum wage law has failed to lift poor working families to the federal poverty line. In 2007, the federal minimum wage level was $57 \%$ of the "living wage" (the wage that puts a family of four on the federal poverty line), down from $81 \%$ in 1979 and 94\% in 1964. The Gini coefficient has been steadily on the rise in the United States since the beginning of the neoliberal era of the 1980s (graph 1). Real average family income has barely changed for the poorest 20\% of the population between 1979 and 2006, while the richest 20\% saw their income rise by $56.77 \%$ and the richest $5 \%$ enjoyed an $87.47 \%$ increase (graph 2). And to make things worse for middle- and lowincome groups, U.S. tax policy took a regressive turn, shifting the burden heavily on those groups (graph 3). According to United for a Fair Economy, since 1980, the top federal tax rates on capital gains has declined by $31 \%$ and the estate tax dropped by $46 \%$, while payroll tax has increased by 25\% (United for a Fair Economy 2006: 23). 
Graph 2. Real Mean Family Income Growth by Quintile and for Top 5\% (19792006)

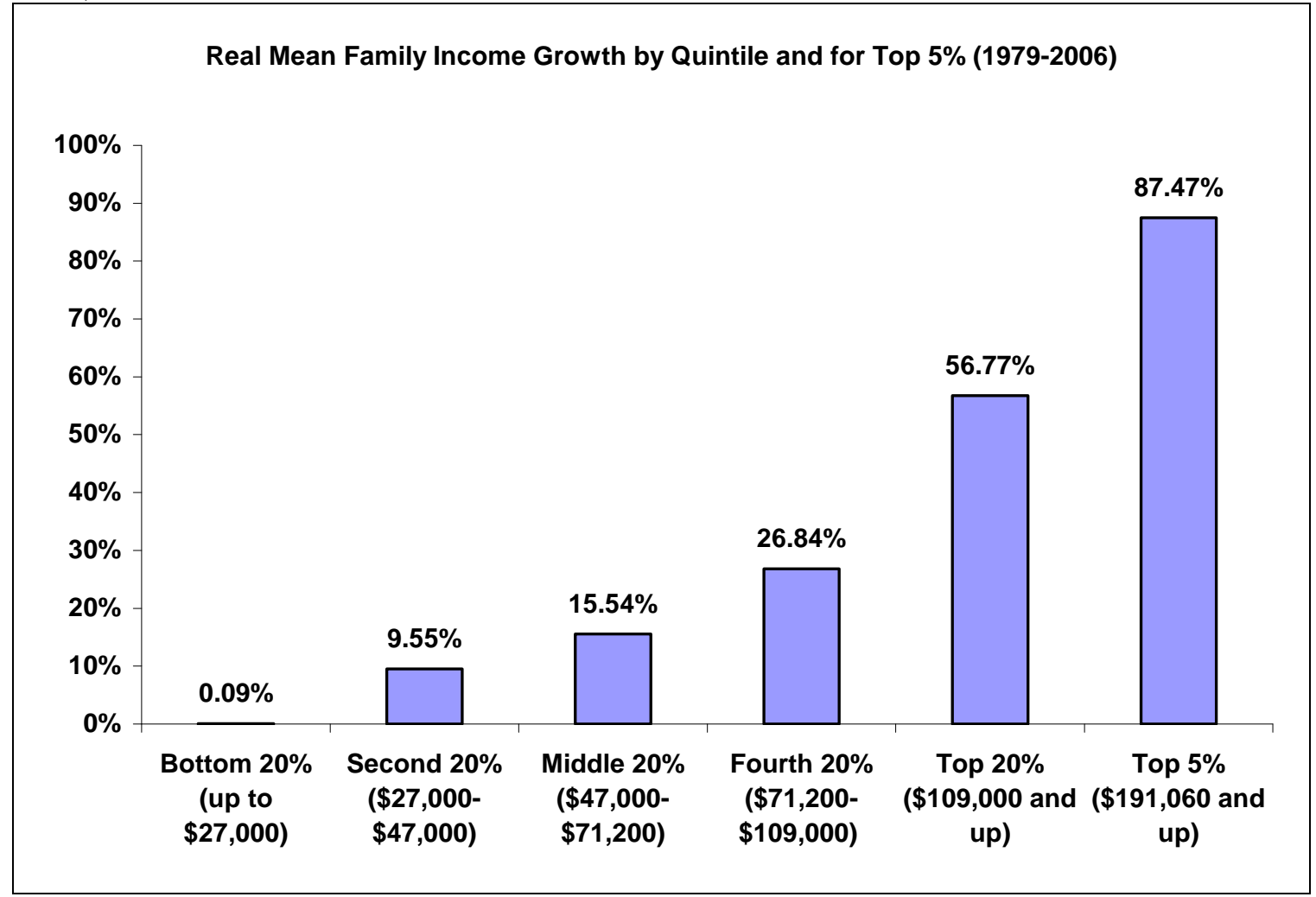

Source: U.S. Census Bureau, and authors’ calculations (2006 dollars) 


\section{Graph 3. Effective Federal Tax Rates (Income Tax + Payroll Tax) for the Top 1\% and the Middle Quintile of Households (1948-2003)}

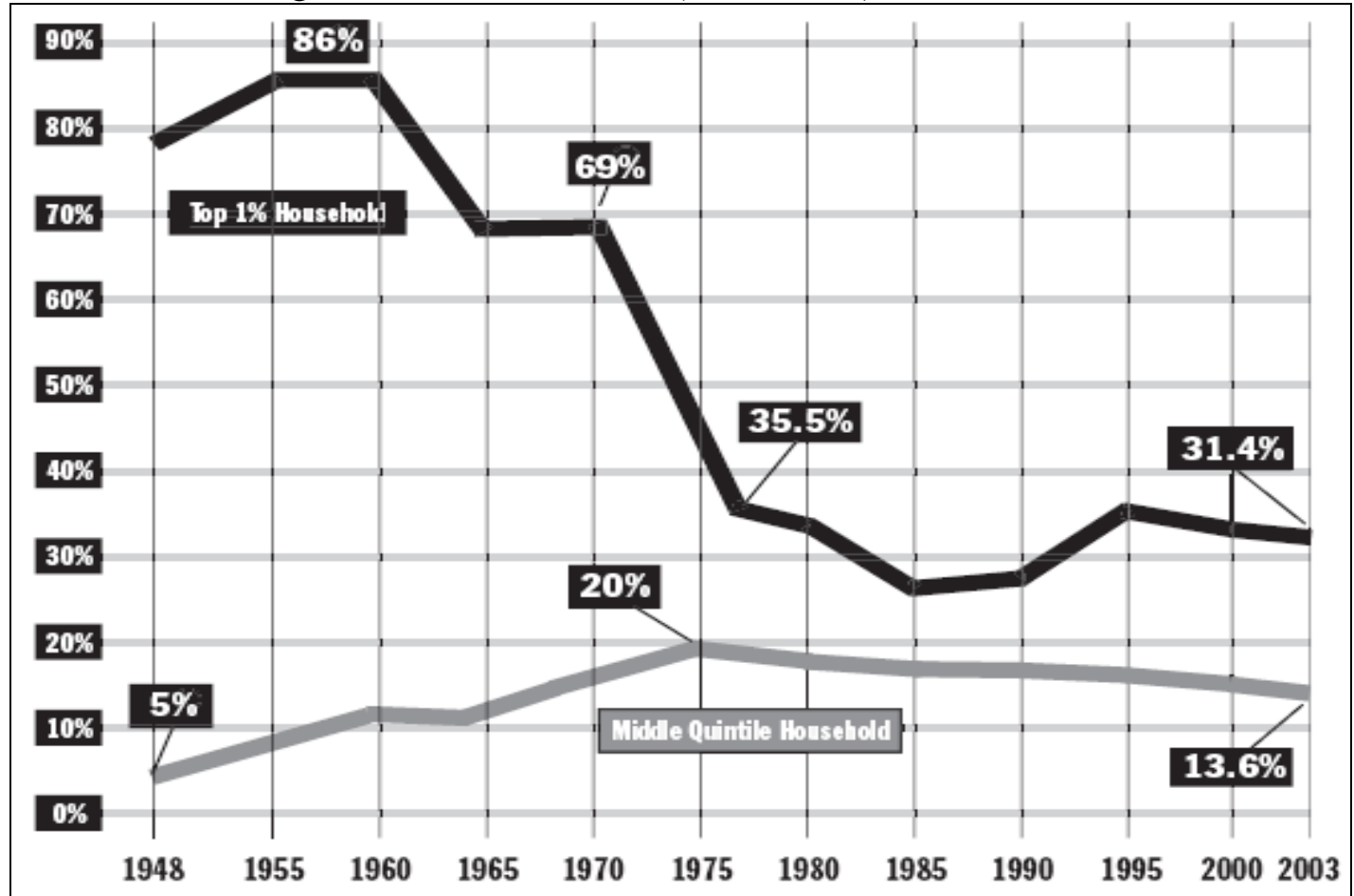

Source: United for a Fair Economy (2006)

By failing to recognize the destabilizing effect of economic inequality, policy

makers at the highest level in the Federal Reserve Bank (the Fed) welcomed the situation as a great way to keep workers in check and prevent inflationary pressures. Testifying before the Senate Banking Committee in January 1997, Alan Greenspan explained that the gap between productivity gains and wage growth has been a blessing in disguise for the U.S. economy. In other words, “employment insecurity” keeps inflation down. In Greenspan’s words:

As I see it, heightened job insecurity explains a significant part of the restraint on compensation and the consequent muted price inflation. Surveys of workers have highlighted this extraordinary state of affairs. In 1991, at the bottom of the recession, a survey of workers at large firms indicated that 25 percent feared being laid off. In 1996, despite the sharply lower unemployment rate and the demonstrably tighter labor market [. . .] 46 percent were fearful of a job layoff. (Greenspan 1997)

Thus, Greenspan's assessment of the cause of the "extraordinary" and “exceptional” U.S. economic performance in the 1990s was “a heightened sense of job 
insecurity" that has subdued wage gains for workers. These "traumatized workers" are even more compliant when they have a home mortgage to pay every month and cannot risk loosing their home were they to go on strike or be laid off. With Greenspan's blessings, workers experienced a real wage freeze, while the Fed was busy fueling the biggest housing bubble in U.S. history.

Graph 4. Median U.S. House Prices (1975-2008)

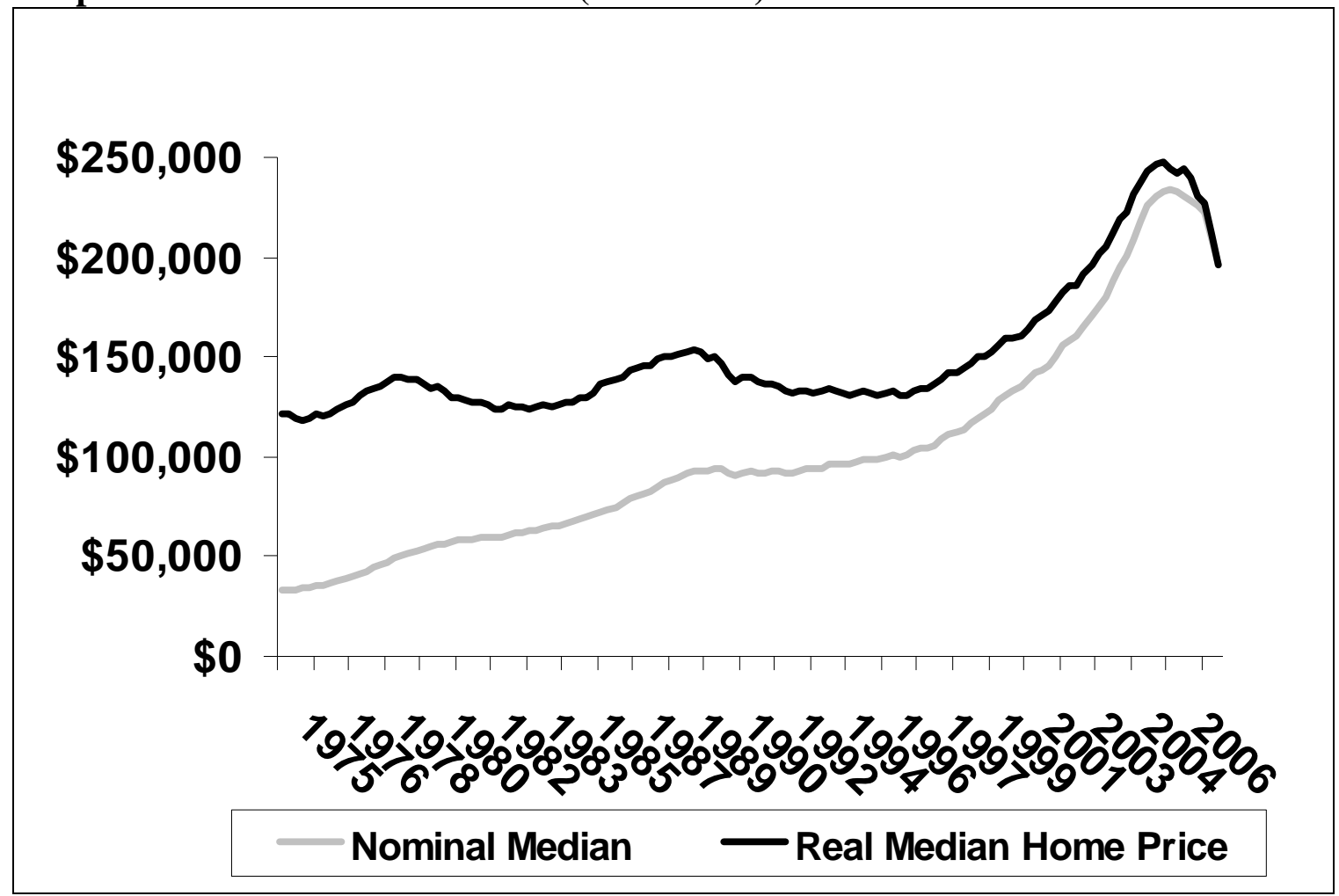

Source: U.S. Census Bureau 


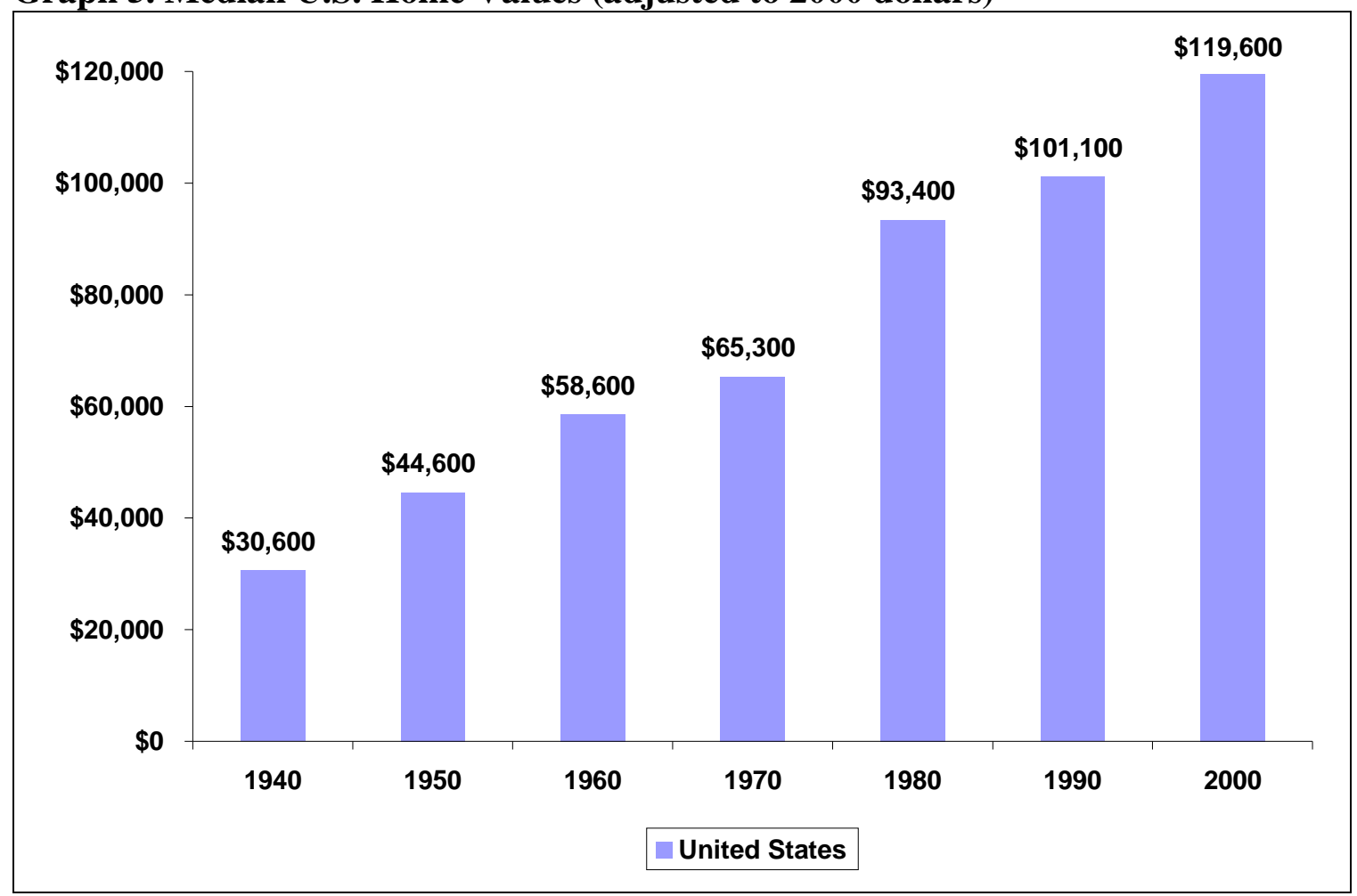

Source: U.S. Census Bureau

The other side of the equation affecting homeownership is the rise in the cost of living, but more importantly, the cost of buying a home. Real median home prices fluctuated roughly between $\$ 120,000$ and \$140,000 (in 2008 dollars) from the mid-1970s to the mid-1990s. However, a sharp increase began to take place in 1996, reaching a peak in 2006 at nearly $\$ 248,000$ (graphs 4 and 5). In short, working families have seen an increase in payroll taxes and more prohibitive home prices, yet no increase in income. The picture is bleak, but thanks to expansive financial deregulation and innovation, working families can still aspire to homeownership through a plethora of home mortgage schemes, including subprime loans. The macroeconomic financial sustainability of the subprime scheme depended on the sustainability of the housing bubble, namely rising home values and low interest rates, both of which disappeared in 2006. Initially, the vast majority of foreclosed homeowners did not loose their jobs; they just couldn't keep up with the higher monthly mortgage payments once interest rates reset at the end of the teaser period. 
Over the last decade, the housing bubble and the artificial improvement in home ownership have been sustained by an extreme reliance on consumer debt given that disposable income was being squeezed by stagnant wages and higher taxes. Consumer debt to income ratio went from 65\% in 1980 to nearly 80\% in the mid-1990 and by 2007 has shot up to over $125 \%$ (graph 6). Furthermore, consumer debt service burden went from $10.5 \%$ in 1995 to a record $14 \%$ in 2006 (graph 7).

\section{Graph 6. Household Debt as a Percent of Disposable Income (in percent, seasonally} adjusted)

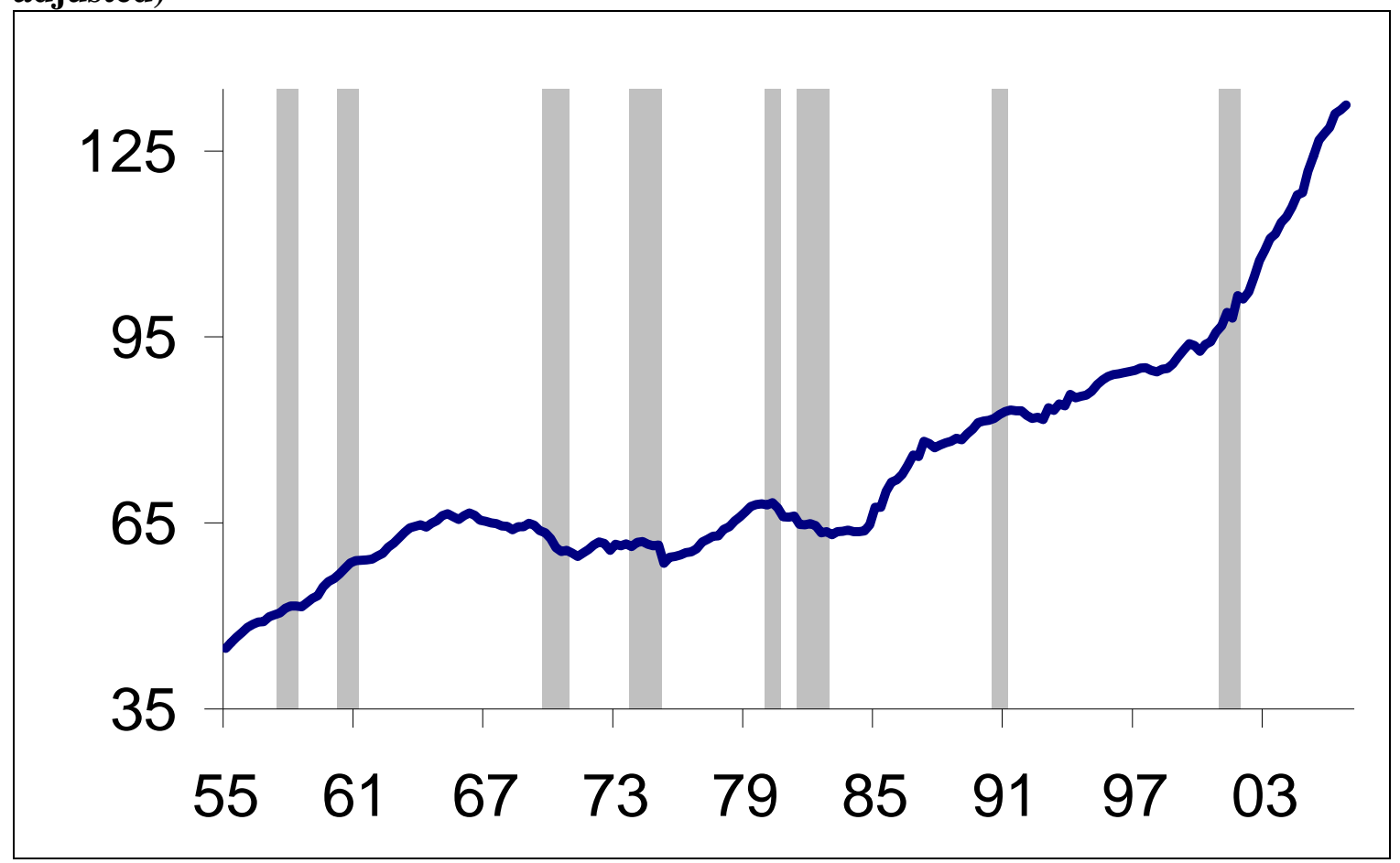

Source: Federal Reserve Bank 


\section{Graph 7. Debt Service Payment as a Percentage of Disposable Personal Income}

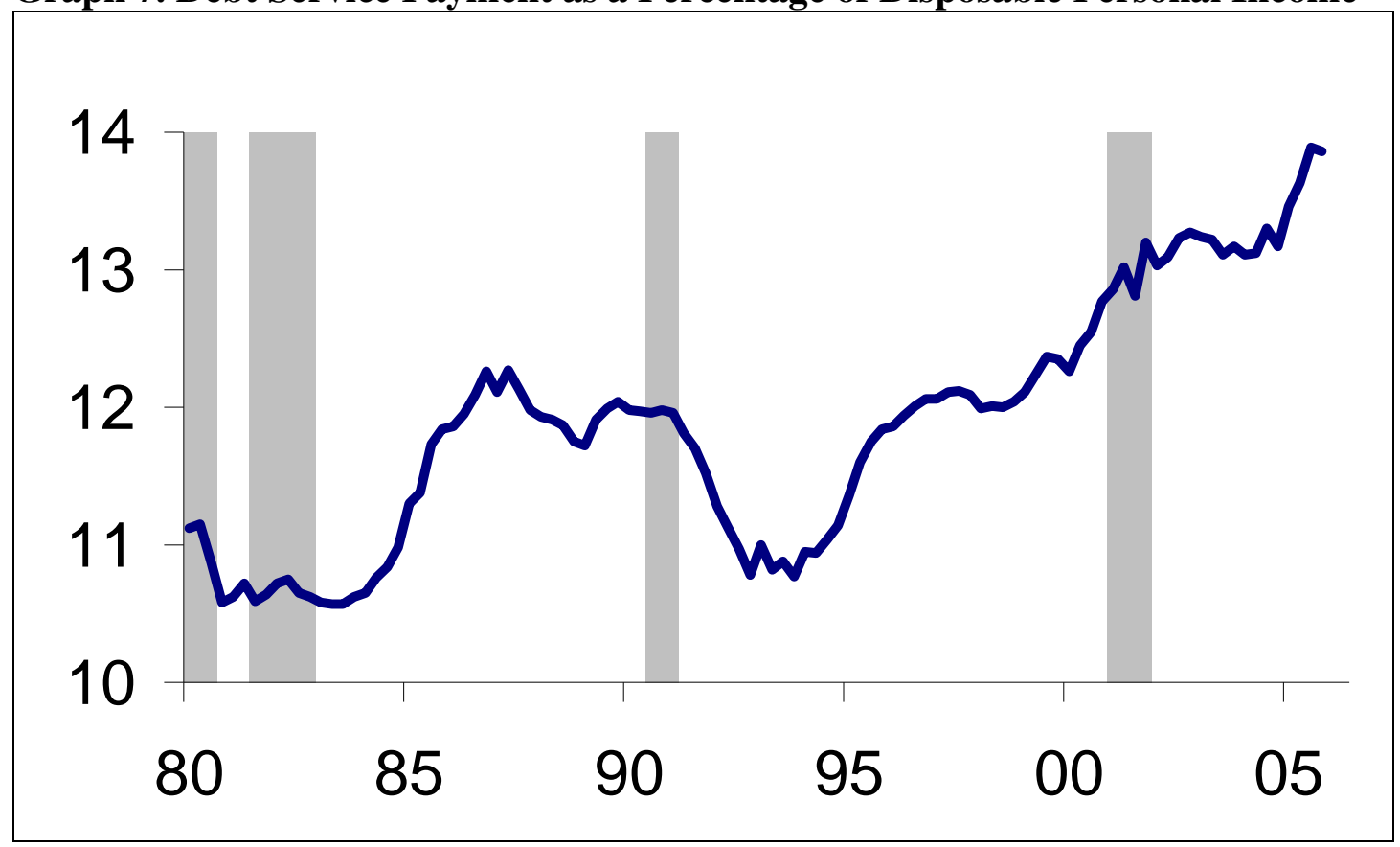

Source: Federal Reserve Bank

When all the pieces of the puzzle are put together, it becomes evident that the rise and intensification of economic hardship on working families was not relived by tax breaks or higher incomes, but rather was further compounded by easy access to consumer debt in the form of mortgage debt, home equity lines of credit, home equity loans, and credit card debt. However, consumer debt can only grow so much since it must be paid down sooner or later. It was these destabilizing effects of inequality that led to financial innovation, predatory lending, and financial turmoil.

\section{FROM “HOMEOWNERSHIP” TO DELINQUENCY AND FORECLOSURE}

National delinquency and foreclosure rates have increased significantly since 2006 as more American homeowners find it difficult to pay their mortgage obligations. The proliferation of “exotic” subprime mortgage products, specifically adjustable rate mortgages (ARMs), during the housing boom of the past six years has been the key contributor to the rise in delinquencies and foreclosures.

Subprime loans are typically made to borrowers who are deficient in either a strong credit history or capacity to repay their loans. The slowdown in home sales and 
rising mortgage rates continue to drive foreclosures at substantially higher numbers than a year ago. Further complicating this issue is the fact that approximately two-thirds of the subprime mortgage debt issued between 2002 and 2004 is due to reset in 2007. Data compiled from the Mortgage Bankers Association corresponding to the third quarter of 2002 to second quarter of 2007 for the United States, South Atlantic, East North Central, and Middle Atlantic regions show that the number of subprime loans serviced has increased considerably in recent years. The persistent rise of seriously delinquent and foreclosure rates across the United States and within specific regions reflect this surge of subprime loans.

From the third quarter of 2002 to the second quarter of 2007, the growth change in the number of prime loans serviced fluctuated from the five year low to high (graph 8). Nationwide, the number of prime loans serviced reached a high of 5.4\% in the third quarter of 2003, but this trend changed to slight decreases and modest increases until it remained unchanged by the end of the second quarter of 2007. The South Atlantic (SA) region $^{2}$ mirrored the national trend. The Middle Atlantic (MA) region ${ }^{3}$ experienced modest lows and highs in the past five years. In the MA region, the number of prime loans serviced fell by $1.2 \%$ in the first quarter of 2003, but rose by $3.9 \%$ in the second quarter of 2005. The number of prime loans serviced in the MA region dropped by $1.7 \%$ by the end of the second quarter of 2007. The East North Central (ENC) region ${ }^{4}$ has been shown to be more volatile than the other regions. Since the third quarter of 2003, the ENC has experienced three major declines and five major peaks.

\footnotetext{
${ }^{2}$ U.S. Census Bureau defines the South Atlantic region as Delaware, District of Columbia, Florida, Georgia, Maryland, North Carolina, South Carolina, Virginia, and West Virginia.

${ }^{3}$ U.S. Census Bureau defines the Middle Atlantic region as New Jersey, New York, and Pennsylvania.

${ }^{4}$ U.S. Census Bureau defines the East North Central region as Indiana, Illinois, Michigan, Ohio, and Wisconsin.
} 
Graph 8. Growth Change in Prime Loans Serviced by Region, 3Q_2002 to 2Q_2007

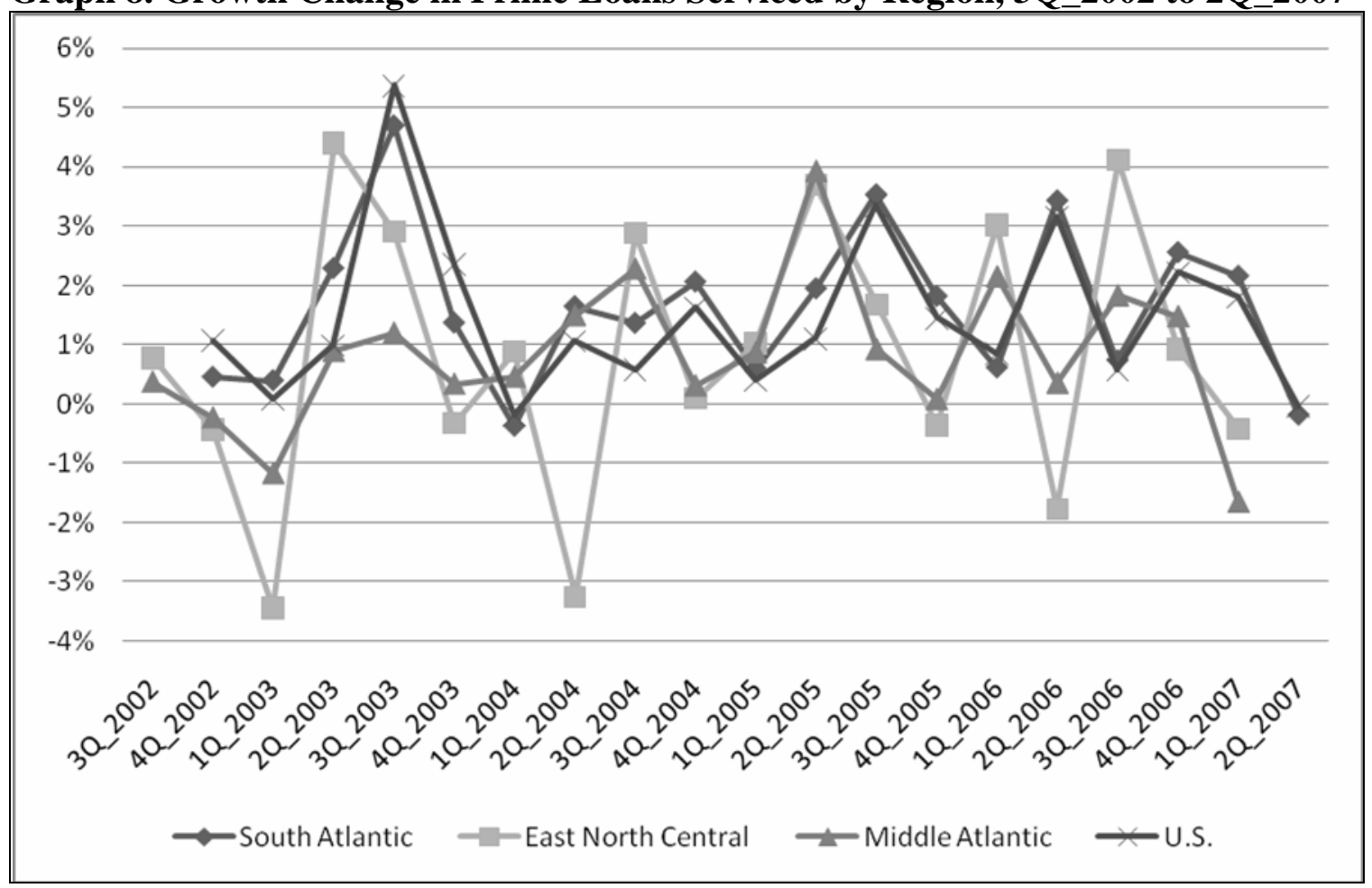

Source: Mortgage Bankers Association (2007)

The growth change in the number of subprime loans serviced from the third quarter of 2002 to the second quarter of 2007 illustrates a more persistent upward trend nationwide and across regions (graph 9). All regions had a surge in the number of subprime loans serviced in the fourth quarter of 2003. The number of loans serviced nationwide rose by $105.4 \%$ in the fourth quarter of 2003. Similarly, in the South Atlantic, Middle Atlantic, and East North Central regions, the number of subprime loans serviced climbed by $80.8 \%$, $88.6 \%$, and $85.7 \%$, respectively. 
Graph 9. Growth Change in Subprime Loans Serviced by Region, 3Q_2002 to 2Q_2007

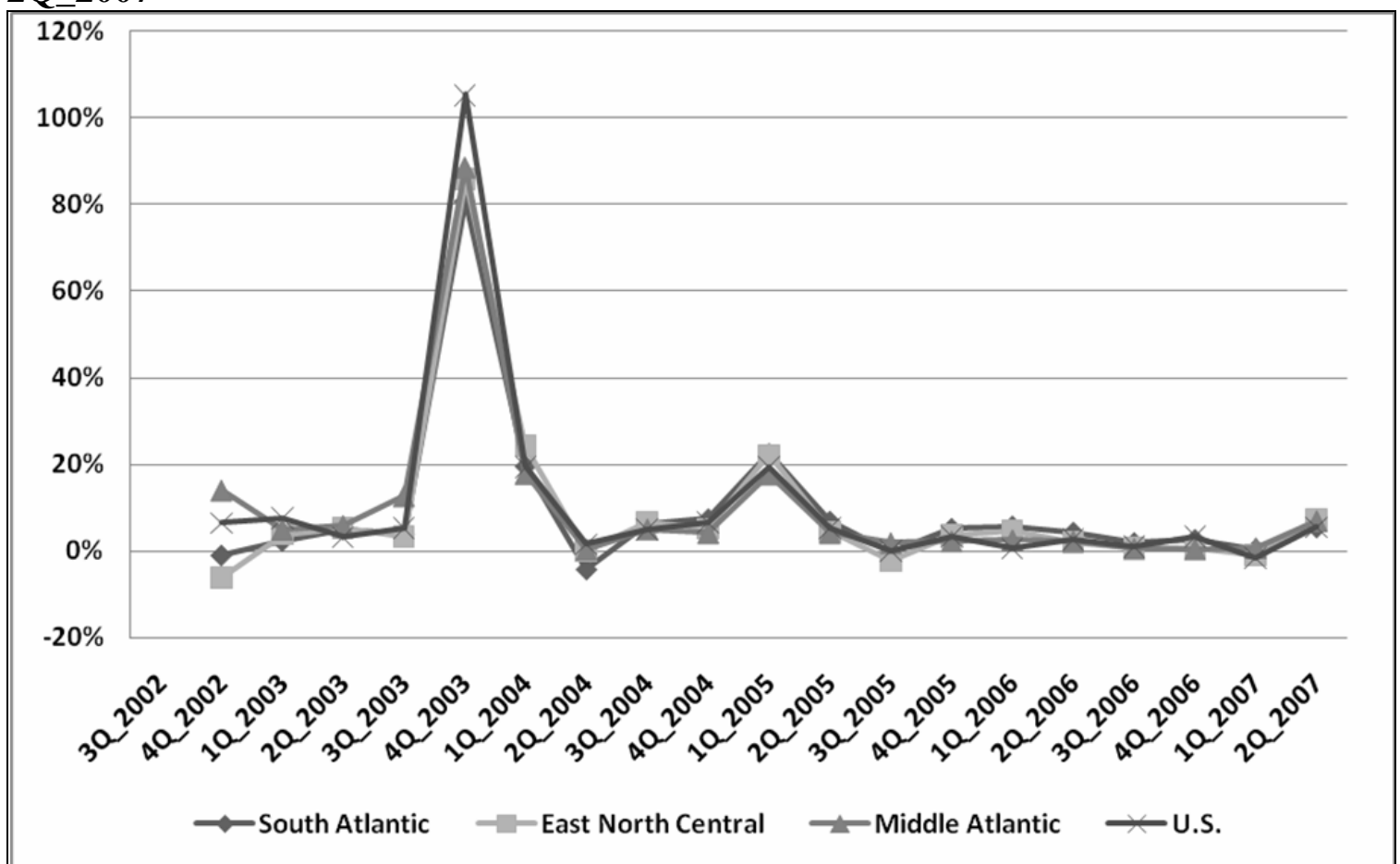

Source: Mortgage Bankers Association (2007)

Graph 10 illustrates the percentage of prime and subprime loans that are past due. Loans considered in this category are between 30 days and 90 days past due. The bottom part of the graph shows the trend in prime loans, while the upper part refers to subprime loans. Across the regions, the percentage of prime loans past due oscillated from $2.0 \%$ to $3.4 \%$. On the other hand, the percentage of subprime loans past due was much higher across the South Atlantic, Middle Atlantic, and East North Central regions. The percentage of subprime loans past due fluctuated between a low of $9.0 \%$ to a high of 17.1\%. The East North Central region had, by far, the highest percentages of subprime past due loans in comparison to the other two regions. 


\section{Graph 10. Total Past Due Prime and Subprime Loans, 2Q_2002 to 2Q_2007}

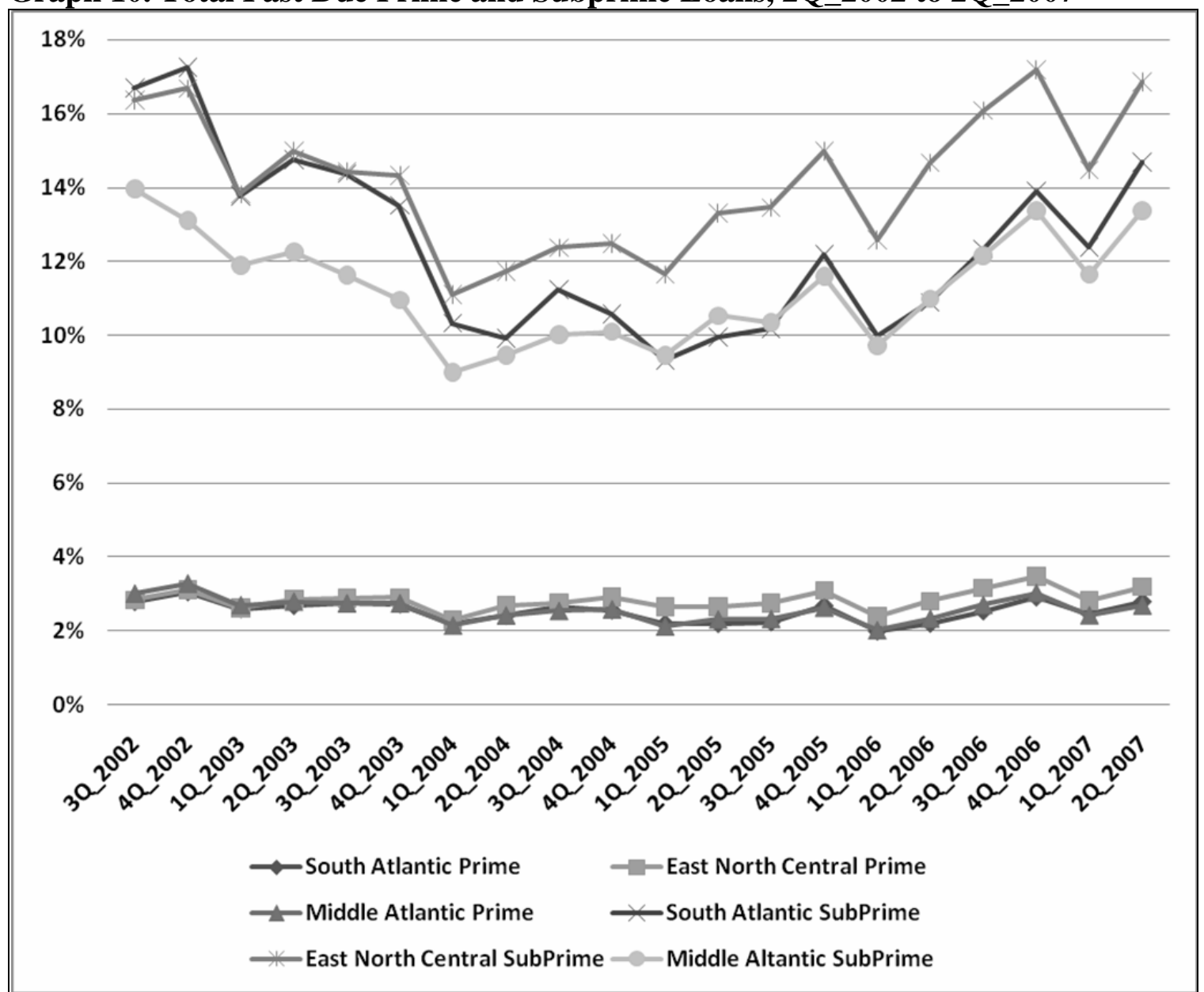

Source: Mortgage Bankers Association (2007)

Table 1 shows the seriously delinquent and foreclosure rates for prime loans ranking among all U.S. states, as well the national rates. In addition, it indicates the growth rate of the seriously delinquent and foreclosure rates from the first quarter of 2007 to the second quarter of 2007. Seriously delinquent prime loans are those that are 90 days or more delinquent or in the process of foreclosure. The seriously delinquency rate is defined as the ratio of all seriously delinquent prime loans to all mortgage prime loans serviced; the same definitions apply to subprime loans. The seriously delinquent rate for the nation was $0.98 \%$, while the foreclosure rate was $0.59 \%$. In the South Atlantic region, West Virginia had the highest delinquency rate (1.24\%), ranking the state seventh in the nation, while South Carolina had the highest foreclosure rate (0.72\%) among its counterparts, raking the state ninth in the United States. In the East North Central region, Ohio had the highest seriously delinquent and foreclosure rate in the nation with $2.17 \%$ 
and $1.57 \%$, respectively. Pennsylvania, in the Middle Atlantic region, reported a seriously delinquency rate of $1.15 \%$, ranking the state eleventh nationwide. Pennsylvania's foreclosure rate was also the highest among the region with $0.69 \%$, ranking the state fourteenth in the United States.

Table 1. Seriously Delinquent, Foreclosure Rates, Ranking and Growth Rates on Prime Loans, 2Q_2007

\begin{tabular}{|c|c|c|c|c|c|c|}
\hline \multirow[b]{2}{*}{ State } & \multicolumn{3}{|c|}{ Seriously Delinquent } & \multicolumn{3}{|c|}{ Foreclosure Rates } \\
\hline & Rate & Ranking & $\begin{array}{l}\text { \% Change } \\
\text { Previous } \\
\text { Quarter }\end{array}$ & Rate & Ranking & $\begin{array}{c}\text { \% Change } \\
\text { Previous } \\
\text { Quarter }\end{array}$ \\
\hline \multicolumn{7}{|c|}{ South Atlantic } \\
\hline Delaware & 1.01 & 19 & 0.30 & 0.71 & 11 & 0.27 \\
\hline District of Columbia & 0.53 & 43 & 0.06 & 0.27 & 45 & 0.04 \\
\hline Florida & 0.99 & 21 & 0.23 & 0.59 & 24 & 0.15 \\
\hline Georgia & 1.16 & 10 & 0.03 & 0.67 & 15 & 0.02 \\
\hline Maryland & 0.54 & 42 & 0.13 & 0.29 & 44 & 0.09 \\
\hline North Carolina & 0.85 & 29 & -0.05 & 0.49 & 29 & -0.03 \\
\hline South Carolina & 1.14 & 12 & -0.08 & 0.72 & 9 & -0.07 \\
\hline Virginia & 0.46 & 47 & 0.07 & 0.21 & 48 & 0.03 \\
\hline West Virginia & 1.24 & 7 & 0.13 & 0.69 & 13 & 0.07 \\
\hline \multicolumn{7}{|c|}{ East North Central } \\
\hline Illinois & 1.06 & 14 & 0.03 & 0.72 & 10 & 0.01 \\
\hline Indiana & 1.91 & 2 & -0.05 & 1.38 & 2 & -0.02 \\
\hline Michigan & 1.86 & 3 & 0.23 & 1.17 & 3 & 0.18 \\
\hline Ohio & 2.17 & 1 & -0.02 & 1.57 & 1 & -0.01 \\
\hline Wisconsin & 1.02 & 18 & 0.05 & 0.70 & 12 & 0.02 \\
\hline \multicolumn{7}{|c|}{ Middle Atlantic } \\
\hline New Jersey & 0.83 & 30 & 0.04 & 0.52 & 26 & 0.02 \\
\hline New York & 0.79 & 32 & -0.02 & 0.49 & 30 & -0.01 \\
\hline Pennsylvania & 1.15 & 11 & -0.05 & 0.69 & 14 & -0.05 \\
\hline \multicolumn{7}{|c|}{ Nationwide } \\
\hline United States & 0.98 & $\mathrm{n} / \mathrm{a}$ & 0.09 & 0.59 & $\mathrm{n} / \mathrm{a}$ & 0.05 \\
\hline
\end{tabular}

Source: Mortgage Bankers Association (2007)

Table 2 shows the seriously delinquent and foreclosure rates for subprime loans, ranking among all U.S. states, and the growth rate from the first quarter of 2007 to the second quarter of 2007. In the second quarter of 2007, the seriously delinquent rate for the nation was $0.98 \%$, while the foreclosure rate was $0.59 \%$. In the South Atlantic region, Georgia had the highest delinquency rate (10.11\%), ranking the state fourteenth in the nation; South Carolina had the highest foreclosure rate (5.96\%) among its counterparts ranking the state fourteenth in the United States. In the East North Central region, Ohio 
once again topped the charts with the highest delinquency and foreclosure rates nationwide at $16.53 \%$ and $11.85 \%$, respectively. In the Middle Atlantic region, Pennsylvania had the highest delinquency rate in the region with 9.74\%, ranking the state sixteenth nationwide. New Jersey's foreclosure rate was the highest in the region with $5.61 \%$, raking the state twentieth in the United States.

Table 2. Seriously Delinquent, Foreclosure Rates, Ranking and Growth Rates on Subprime Loans, 2Q_2007

\begin{tabular}{|c|c|c|c|c|c|c|}
\hline \multirow[b]{2}{*}{ State } & \multicolumn{3}{|c|}{ Seriously Delinquent } & \multicolumn{3}{|c|}{ Foreclosure Rates } \\
\hline & Rate & Ranking & $\begin{array}{c}\text { \% Change } \\
\text { Previous } \\
\text { Quarter } \\
\end{array}$ & Rate & Ranking & $\begin{array}{c}\text { \% Change } \\
\text { Previous } \\
\text { Quarter } \\
\end{array}$ \\
\hline \multicolumn{7}{|c|}{ South Atlantic } \\
\hline Delaware & 7.35 & 37 & 0.49 & 4.45 & 31 & 0.26 \\
\hline District of Columbia & 6.83 & 39 & 1.08 & 3.27 & 41 & 0.58 \\
\hline Florida & 8.48 & 27 & 2.19 & 5.29 & 22 & 1.54 \\
\hline Georgia & 10.11 & 14 & 0.44 & 5.19 & 24 & -0.03 \\
\hline Maryland & 6.10 & 40 & 0.99 & 2.73 & 46 & 0.38 \\
\hline North Carolina & 7.62 & 36 & 0.02 & 3.81 & 35 & -0.31 \\
\hline South Carolina & 9.94 & 15 & 0.31 & 5.96 & 14 & -0.11 \\
\hline Virginia & 5.84 & 41 & 1.06 & 2.76 & 45 & 0.40 \\
\hline West Virginia & 8.79 & 24 & -0.76 & 3.39 & 39 & -0.76 \\
\hline \multicolumn{7}{|c|}{ East North Central } \\
\hline Illinois & 11.24 & 12 & 1.20 & 7.42 & 9 & 0.63 \\
\hline Indiana & 13.84 & 3 & 0.24 & 9.40 & 3 & -0.17 \\
\hline Michigan & 16.22 & 2 & 0.39 & 10.09 & 2 & -0.17 \\
\hline Ohio & 16.53 & 1 & 0.57 & 11.85 & 1 & 0.13 \\
\hline Wisconsin & 11.47 & 9 & 0.67 & 7.85 & 7 & 0.11 \\
\hline \multicolumn{7}{|c|}{ Middle Atlantic } \\
\hline New Jersey & 8.94 & 20 & 1.26 & 5.61 & 17 & 0.71 \\
\hline New York & 8.57 & 26 & 1.07 & 5.56 & 19 & 0.69 \\
\hline Pennsylvania & 9.74 & 16 & -0.11 & 5.37 & 20 & -0.35 \\
\hline \multicolumn{7}{|c|}{ Nationwide } \\
\hline United States & 9.27 & $\mathrm{n} / \mathrm{a}$ & 0.94 & 5.52 & $\mathrm{n} / \mathrm{a}$ & 0.42 \\
\hline
\end{tabular}

Source: Mortgage Bankers Association (2007)

Wray and Pigeon (2000) illustrate the persistence of unemployment for a significant portion of the population during the Clinton-era expansion. The Clinton boom was a classic demand-led expansion, fueled by consumer spending and increasing consumer debt. The culmination of the cycle was brought to a halt with the dotcom bust and a subsequent reduction in consumer spending. The hardcore unemployed and the economically disadvantaged were simply unable to benefit from the Clinton-era 
expansion. The 2000 recession made it difficult for the real estate market to continue its expansion and growth. Thankfully for the real estate market, the Fed aggressively slashed its fed funds rate target from 6.5\% in May 2000 to 1\% in June 2003, an all-time historical low, and kept it at that rate until June 2004. This four-year period of incredibly low interest rates allowed middle- and high-income consumers to refinance their homes and to pay off some of the debt accumulated in the 1990s. This was bad news for banks and real estate firms because creditworthy customers of middle- and upper-income classes were no longer flooding the market for homes. The next best thing were the subprime borrowers, those who had bad credit, then those who had no credit, then those who had no jobs, no income, and no assets. The lending criteria were consistently relaxed in order to issue the maximum amount of loans (and earn fees and commissions) that would be shipped off to Wall Street financial engineers for MBS and CDO packaging.

This "boom" in homeownership and demand for homes helped jumpstart the residential real estate market and the economy was set for another expansion. But, as the economy began a modest recovery, the Fed immediately sought to bring the fed funds rate back to higher levels, so it began raising rates continuously starting in June 2004 to reach $5.25 \%$ by June 2006. The subprime time-bomb remained unnoticed thanks to the 228 and 3-27 mortgage schemes in which borrowers would pay a very low rate for 2-3 years, but then would reset at rates as high as $12 \%$, thus leading to almost certain default and foreclosure. By the end of 2006, delinquencies on adjustable subprime loans began to rise and, by July 2007, the damage reached major financial institutions in the United States, Germany, France, the United Kingdom, and Switzerland. It seems that the Fed was still not fully aware of the extent of the crisis and had kept its target rate unchanged at 5.25\% until September 18, 2007 when the financial crisis has fully developed.

Ironically, the most disadvantaged group of the population had been used to prevent a prolonged recession in 2001 by introducing the "democratization of homeownership." At the same time, the financial schemes used to promote growth sowed the seeds for the subprime financial meltdown. What was presented as a strategy for “democratizing homeownership" was, in fact, the recipe for democratizing financial turmoil—the taste of which, at least initially, was most bitter among the most disadvantaged groups. 
Homeowners' financial woes are not over yet. The American Bankers Association (ABA) reports that in the first quarter of 2008, late payments on U.S. home equity lines of credit soared to a 21-year high as a result of the subprime crisis. Home equity lines of credit delinquencies (more than 30 days past due) rose to $1.1 \%$ from $0.96 \%$ the prior quarter. This is the highest delinquency rate since the ABA began collecting the data in 1987. The most recent developments leading up to the nationalization of Northern Rock in the United Kingdom, as well as the nationalization of AIG and mortgage giants Freddie Mac and Fannie Mae in the United States confirm the growing magnitude of this crisis. Despite the rising U.S. exports in the first quarter of 2008, which kept GDP growth positive, the unemployment rate jumped to a 5-year high at 6.1\% in August 2008. Higher unemployment (and inequality) is going to be the main catalyst for further economic troubles. In the next section, we outline a policy proposal to deal with the root cause of the subprime crisis, namely inequality.

\section{EMPLOYMENT-LED REMEDY TO INEQUALITY AND FINANCIAL INSTABILITY}

Despite the popularity of Minsky's work on the financial instability hypothesis, most of his work has been on issues of employment and job creation policies to fight poverty (Minsky 1965a,1965b). Minsky implicitly recognized the role of inequality in destabilizing the financial system and the economy in general. Our policy proposal here is nothing but an updated version of Minsky's employer of last resort (ELR) program, which we suggest as the only viable solution for the real democratization of homeownership. Under conditions of real income growth stagnation combined with everincreasing real estate prices, there can be no market-based solution for boosting homeownership. An ELR program can guarantee a real employment opportunity for all at a socially established living wage (Minsky 1986a; Wray 1998; Mosler 1997-98 Forstater and Wray 2004).

Minsky's philosophy about job creation is one in which the government would “take workers as they are” and provide “on-the-job training” when required. Minsky's aim is to have the government establish a decentralized job-creation system whereby it 
would create an infinitely elastic demand for labor. The government would hire anyone who is ready, willing, and able to work. Jobs would be selected by local community groups and nonprofit organizations based on the social benefits to the community. The implementation and management of ELR projects would be locally-based, whereas funding would be provided by the federal government. ELR projects would be selected to match the skills of the local unemployment pool and would not compete with projects already undertaken by the private sector (or the traditional government sector). ELR would stabilize economic activity at full employment, so when the private sector slows down, the ELR administration would hire more ELR workers; as the private sector recovers, it can hire ELR workers away from the government at a premium above the ELR wage. The government therefore creates a buffer-stock of labor to stabilize wages and inflation. Stable employment and rising income is the only secure mechanism to ensure a consistent rise in homeownership.

Most critics claim that the cost of the program would be prohibitive and that it would lead to massive budget deficits and rising national debt. Several reliable estimates, however, have shown that the cost of implementing ELR in the United States is around 1\% of GDP (Gordon 1997; Majewski and Nell 2000; Majewski 2004; and Fullwiler 2007). The establishment of an ELR program would also produce substantial cost savings, as it would make several government assistance programs redundant. The cost of implementing ELR is, by far, lower than the trillions of dollars that are being spent now on government bailouts of Wall Street firms. Job guarantee ensures that homeowners can qualify for affordable loans and that they don't miss any mortgage payments, which, in turn, ensures the stability of the mortgage-backed securities market. ELR doesn't eliminate inequality all together, but it puts a floor to income and aggregate demand levels. Furthermore, ELR introduces a sense of security and confidence, so it stabilizes expectations. When employment is guaranteed, consumers and businesses can engage in long-term planning based on stable aggregate demand.

The establishment of ELR would also require a substantial coordination of fiscal and monetary policies between the Fed and the Treasury to ensure the establishment of full employment and price stability simultaneously. The financing of the program would be done in the same way as any other government program. Government spending injects 
reserves into the economy, then taxes or bond sales would withdraw excess reserves from the system, thus preventing inflationary pressures and keeping overnight interest rates at the desired policy target. There can be no financing constraint on the monopoly issuer of the currency. A financially sovereign government has the ability to finance any economic activity it wishes to undertake, since it can issue debt denominated in the sovereign's own currency and collect taxes in that same currency. According to the basic principles of functional finance, the ELR program will add to the annual deficit and the national debt, but those levels are just accounting indications of the private sector's desire to net save and do not represent any financial burden on the government. It is the function of the deficit and the national debt that matters, not their levels. The desired function here is to address the root cause of the financial crisis (i.e., income inequality) through a job guarantee program. Without an ELR program, all other attempts at improving homeownership will remain artificial and, therefore, temporary at best. The massive government bailout of Wall Street firms, though necessary, is yet another temporary patch to the system and does not deal with the root cause of the problem.

\section{CONCLUDING REMARKS}

The paper presented a critique of the ill-conceived policies of increasing homeownership in the United States. We explained the subprime crisis with Minsky's financial instability hypothesis. The system according to Minsky is inherently unstable. Financial crises are not the result of irrational exuberance, but rather deep structural flaws that are inherent to capitalist systems. We identified that inequality has been the main structural cause of the subprime crisis. When aggregate demand began to fall in the late 1990s as over-indebted consumers began to slow their borrowing, the real estate lending frenzy went after subprime borrowers with exotic lending schemes to put a temporary patch on inequality, claiming the "democratization of homeownership." The scheme spread to Wall Street through securitization. The highly complicated structured investment vehicles have consequently become too illiquid and almost impossible to value, and have turned into toxic assets on the balance sheets of all major financial institutions. 
We argue that fixing the financial crisis through a bailout of any sort will, at best, restore temporary financial stability and will not address the root cause of the problem. We propose attacking the problem at its roots through a job guarantee program that ensures that homeowners have access to a decent employment opportunity. This would help homeowners keep their homes and provide stability to real estate values, thus indirectly stabilizing the mortgage-backed securities market and financial markets in general. The data illustrates the extent to which inequality over the last four decades has built up an economic iceberg with stagnant income, rising cost of living and home prices, and little or no real assistance for low-income homebuyers. The subprime lending schemes with cheap money financing came as a fictitious and temporary remedy for lowincome groups seeking homeownership. The mirage disappeared as interest rates rose, cheap financing disappeared, and home values plummeted. The end result was a “democratization of financial turmoil” rather than “democratization of homeownership.”

The proposed $\$ 700$ billion government bailout of Wall Street will only set the system up for another financial crisis down the road if it is not supplemented with a comprehensive plan to restore income growth and debt relief for middle- and low-income groups. The most efficient and productive way to do this is through a job guarantee program à la Minsky, which will achieve full employment, price stability, financial stability, rising standards of living, and increased actual homeownership. 


\section{BIBLIOGRAPHY}

Bernanke, Ben S. 2004. "The Great Moderation.” Speech given at the meeting of the Eastern Economic Association, February 20. Washington, DC.

Chancellor, Edward. 2007. “Ponzi Nation.” Institutional Investor, February 7.

Forstater, Mathew, and L. Randall Wray. 2004. "Full Employment and Social Justice.” in Champlin and Knodler (eds.), The Institutionalist Tradition in Labor Economics. Armonk, NY: M.E. Sharpe, Inc.

Fullwiler, Scott T. 2007. "Macroeconomic Stabilization through an Employer of Last Resort." Journal of Economic Issues 41(1): 93-134.

Gordon, Wendell. 1997. “Job Assurance: The Job Guarantee Revisited.” Journal of Economic Issues 32(3): 826-834.

Greenspan, Alan. 1997. "Statements to Congress-Statements by Alan Greenspan to the Senate Committee on the Budget and the Senate Committee on Finance, U.S. Senate, January 21, 1997.” Federal Reserve Bulletin (March).

Kaboub, Fadhel. 2007a. "Employment Guarantee Programs: A Survey of Theories and Policy Experiences.” Working Paper 498. Annandale-on-Hudson, NY: The Levy Economics Institute of Bard College.

. 2007b. "Institutional Adjustment Planning for Full Employment.” Journal of Economic Issues 41(2): 495-502.

Keynes, John M. 1936. The General Theory of Unemployment, Interest, and Money. New York: Harcourt, Brace, and World, Inc.

Kregel, Jan. 2007. "Minsky’s Cushions of Safety: Systemic Risk and the Crisis in the U.S. Subprime Mortgage Market.” Public Policy Brief 93. Annandale-on-Hudson, NY: The Levy Economics Institute of Bard College.

Lahart, Justin. 2007. "In Time of Tumult, Obscure Economist Gains Currency.” The Wall Street Journal, August 18.

Majewski, Raymond. 2004. "Simulating an Employer of Last Resort Program.” in Argyrous, Forstater, and Mongiovi (eds.), Growth, Distribution, and Effective Demand: Alternatives to Economic Orthodoxy, Essays in Honor of Edward J. Nell. Armonk, NY: M.E. Sharpe Inc. 
Majewski, Raymond, and Edward J. Nell. 2000. "Maintaining Full Employment: Simulating an Employer of Last Resort Program.” Seminar Paper No. 6. Kansas City, MO: Center for Full Employment and Price Stability (CFEPS). Available at: http://www.cfeps.org/pubs/sp/sp6.html

Minsky, Hyman P. 2008. “Securitization.” Policy Note 2. Annandale-on-Hudson, NY: The Levy Economics Institute of Bard College.

- 1992a. "Reconstituting the United States' Financial Structure: Some Fundamental Issues.” Working Paper 69. Annandale-on-Hudson, NY: The Levy Economics Institute of Bard College.

. 1992b. "The Financial Instability Hypothesis.” Working Paper 74. Annandaleon-Hudson, NY: The Levy Economics Institute of Bard College.

. 1986a. Stabilizing an Unstable Economy. New Haven, CT: Yale University Press.

. 1986b. "Global Consequences of Financial Deregulation." in Gary Clyde Hufbauer (ed.), The Marcus Wallenberg Papers on International Finance, Volume 2, Number 1. Washington, DC: Georgetown University.

. 1965a. "The Role of Employment Policy.” in M.S. Gordon (ed.), Poverty in America. San Francisco: Chandler.

. 1965b. "Labor and the War Against Poverty." The Center for Labor Research and Education. Berkley, CA: Institute of Industrial Relations.

Mortgage Bankers’ Association. 2007. National Delinquency Survey, 2nd Quarter.

Mosler, Warren B. 1997-98. "Full Employment and Price Stability.” Journal of Post Keynesian Economics 20(2): 167-182.

The White House. 2004. "President George W. Bush: A Remarkable Record of Achievement.” August. Washington, DC. Available at: http://www.whitehouse.gov/infocus/achievement/Achievement.pdf

The White House. 2002. "President Calls for Expanding Opportunities to Home Ownership.” June 17. Washington, DC. Available at: http://www.whitehouse.gov/news/releases/2002/06/20020617-2.html

United for a Fair Economy. 2006. "The Growing Divide: Inequality and the Roots of Economic Insecurity.” October. Available at: www.faireconomy.org 
Whalen, Charles. 2007. “The U.S. Credit Crunch of 2007: A Minsky Moment.” Public Policy Brief 92. Annandale-on-Hudson, NY: The Levy Economics Institute of Bard College.

Wray, L. Randall, and Marc-Andre Pigeon. 2000. “Can a Rising Tide Raise All Boats? Evidence from the Clinton-era Expansion.” Journal of Economic Issues 34(4): 811-845.

Wray, L. Randall. 2007. “Lessons from the Subprime Meltdown.” Working Paper 522. Annandale-on-Hudson, NY: The Levy Economics Institute of Bard College.

. 1998. “Zero Unemployment and Stable Prices.” Journal of Economic Issues 32(2): 539-546. 